\title{
جاهمة واسط ودورها في تنمية الموارد البشرية
}

م. د. نزار عبد السادة نسار نصار

كلبة الآداب - بامعة واسنط

الاقدهمة

الجامعة مؤسسة اجتماعية أوجدها المجتمع خدمة لأهدافه، تؤثر فيه عبر ما تقوم به من وظائف وتتأثر به بما يحيط بها من تغير ات تفرضها أوضاع المجتمع وحركته ، لذا من الطبيعي أن تكون جزءا غير منعزل عن هذا المجتمـع ومـا يو اجهها مـن تحديات ومشكلات وطموحـات وآمـال ، فـالتطور ات العلمية و التقنية ومـا يترتب عليها من ثورة في عالم الاتصـالات ومـا ارتبط بهذا كله من تغيرات في أحو ال المجتمع قد اوجد مسؤوليات إضـافية على الجامعة للمشـاركة الفعالـة في دعم مسيرة التنميـة ، و الاستجابة بطريقة مرنة وفعالة على الوجه الذي يحقق رسالتها في المجتمع وينهض بدور ها الطبيعي في قيادة هذا المجتمع ' لذلك تسـاهم الجامعـة في عملية التنميـة الاقتصـادية و الاجتماعيـة عن طريق الدور الذي تقوم بـه بتهيئة الظروف المناسبة للأفر اد و المؤسسـات العاملـة في المجتمع للاستفادة مـن الإمكانـات الماديـة و البشـرية و العلميـة و الصـحية و الرياضـية كافـة في الجامعـة ، وتنميـة و عي الأفر اد ومهار اتهم في شتى المجالات في سبيل الوصـول الى النمو الاقتصـادي و الاجتماعي السريع و اللحساق بالتقدم المذهل في التقنيات و الابتكار ات الحديثة. و الأمن الاجنماعي على صلة وثيقة بالعقل البشري وبكيفية توظيف هذا العقل ، وهو أمر على صلة بالتربية التي يتعرض لها الإنسـان ، وبالثقافة التي يطور ها ، ونحن اليوم في العراق نتطلع الى مجتمع آهن يسود فيه القانون و القيم السـامية و المسـاو اة وتحترم في نطاقه إنسانية الإنسـان وكر امته وتبرز فيه حركة التعاون على الخير و العطاء بين فئاته و أفر اده كافة و البعد عن التطرف و التعصب المقيت . من هنا يأتي التأكيد على أهمية دور الجامعات في تعزيز الأمن و السلم الاجتمـاعيين و التأكيد على اعتماد الحو ار البناء و التسـامح وضرورة الحفاظ على مبدأ الثر اكة المجتمعية و العمل على رفع مستوى الوعي للى الطلبة وفي المجالات كافة .

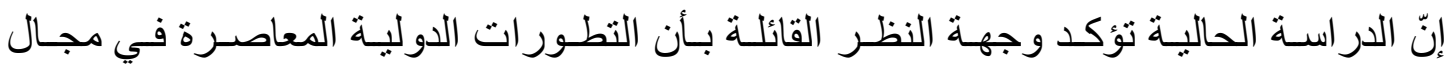
الاتصـالات و المعلومـات تجعل مـن تطوير دور الجامعـة والوظـائف التـي تقوم بهـا إحدى ضـرورات الاستجابة المطلوبة لتحديات هذا العصر ، وما تسعى إلبه من تطوير للإضافات و التخصصـات التطبيقية للتعليم الجـامعي ، وتحديث الإمكانـات البحثية و التقنيـة والقدر ات التكنولوجيـة للجامعـات من جانـب ، و المساهمة الايجابية الفاعلة في تنمية المجتمع وتحديثه في الجانب الآخر . 


\section{المهور الاول : الباهمة هفهوهها ونشأتها:}

او لا : نشأة و تأسيس جامعة واسط : في عام ب . . ب برز في محافظة و اسط صر ح علمي طالما حلم بـه

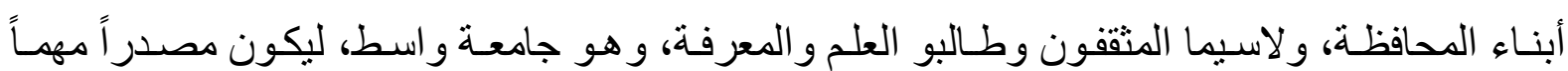
و أساسياً في إثـاعة نور المعرفة و العلم و الثقافة في ربوع وأرجـاء المحافظة، وليلبي الحاجـة الماسـة

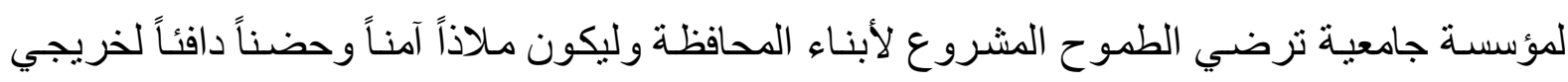
المرحلة الإعدادية من أبناء المحافظة.

كليات الجامعة: احتضنت الجامعة ثلاث كليات كانت مرتبطة إدارياً و علمياً بجامعة القادسية، فكانت هذه الكليات اللبنات الأولى لجامعة واسط، هي: كلية التربية التي استقبلت طلبتها في العام الدر اسي 999 1 ـ -

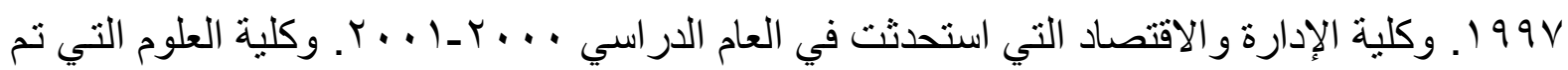

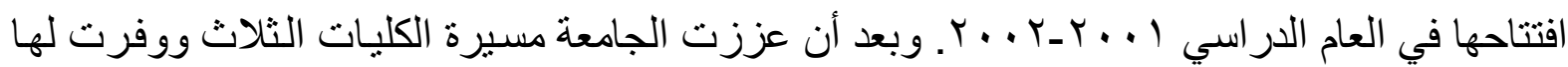
مستلزماتها وز ادت مـن إمكاناتها وملاكاتها، بدأت في العـام الدر اسـي ه . . _ _ . . . حملـة لاستحداث الكليات والأقسام و المر اكز الجديدة؛ فتم افتتاح كليات: كليـة الآداب وتضم الاقسـام :قسم اللغنة العربيـة وقسم الاجتمـاع وقسم الفلسفة وقسم الدر اسـات الثـرقية، وقسم الترجمـة وكليـة الطب، وكليـة الهندسـة وتضـم الاقسـام الهندسـة المدنيـة والميكانيكيـة، وكليـة القانون وتضـم فرع القـانون العـام وفرع القـانون الخاص. وكلية الزر اعة وتضم الاقسام قسم الإنتاج الغذائي و الحيو اني وقسم التربة وتقنيات الري وكلية التربية الاساسية وتضم الاقسام :قسم اللغة العربية وقسم العلوم العامة وكلية الطب البيطري وكلية طب

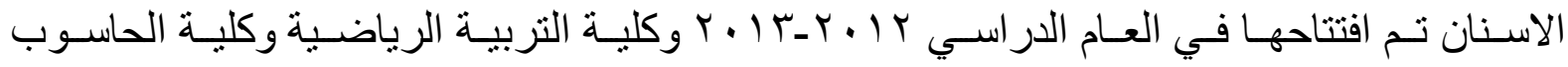
و الرياضيات وكلية الاعلام وكلية الفنون الجميلة

\section{راسالة الباهمعة وخططها المستقبلية}

وضعت إدارة جامعة واسط نصب عينها منذ مرحلة التأسيس جملة أهداف، سعت ولا تز ال

تسعى من أجل تحقيقها، أهمها:

ـ توفير الملاكات العلمية المتقدمة في مختلف المجالات الإنسانية و العلمية، لسد حاجة البلد و الإسر اع في تحقيق أهداف التنمية العلميـة و الاقتصـادية و الاجتماعيـة، وتأمين ملاكات مؤ هلة أكاديمياً للتدريس في الجامعات.

ـ إجر اء البحوث و تقديم الاستشـار ات العلمية للجهات و المؤسسات كافة وتطوير الاختصاصـات الدقيقة و العناية بها.

ـ الإسهام في تطوير الخبر ات و الكفاءات في الاختصاصات كافة من خلال البحوث و الدر اسات العليا. 
ـ النهوض بالو اقع الجديد من خلال إقامة الفعاليات و الندو ات و المؤتمر ات وبناء طاقات أكاديمية لتطوير حركة التعليم العالي و البحث العلمي.

رؤساء الباهمعة

تولى رئاسة الجامعة عدد من الأسـاتذة الأفاضل الذين تميزو ا بالمستوى العلمي الرفيع و القيادة الإدارية المحنكة، وكان لكل منهم أسلوبه القيادي الخاص الذي تجسد بالإنجاز ات العلميـة والماديـة، ولم

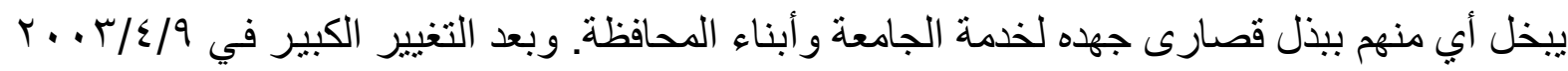
جرت لأول مرة في تاريخ الجامعة عملية انتخاب رئيس جامعة، فوقع اختيار أغلبية أساتذة الجامعة على الأستاذ الدكتور جعفر عبد الكاظم، فتولى مهمـة رئاسـة الجامعة في V/ V/ V . . Y، وقد واجه عقبـات كبيرة أهمها عدم امتلاك الجامعة أي قطعة ارض أو بناية مسجلة رسميا باسمها، إلا أن العمل الدؤوب، و السعي الحثيث ذلل الكثير من هذه العقبات، و استمر في عمله إلى ه/9/0 . . ب، إذ تسلم المسؤولية بعد

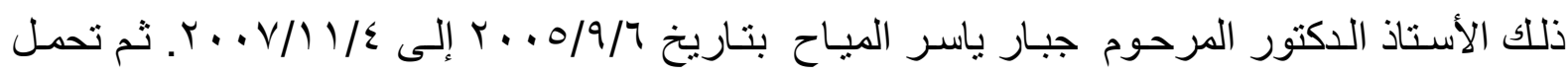

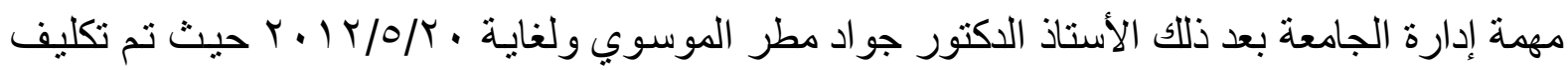
الأسـتاذ الـدكتور تقي الموسـوي رئسيس الجامعـة المستتصـرية السـابق لرئاسـة جامعـة و اســـو لغايـة

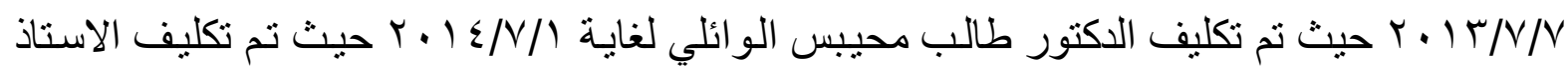
الدكتور عبد الرزاق احمد النصبري بمهام رئاسة الجامعة .

\section{ثانيا : هفهوم الجاهعة :}

عند العودة إلى المعجم العربي والبحث في بطونـه نجد أن المعنى البسير للجامعة ومشتقاتها الجمع و الجماعة والمجموعة وصيغها الأخرى ير اد بها تضـافر التواجد الذي يؤدي بدوره إلى تضـافر الجهود و الطاقـات بغيـة توظيفهـا لخدمـة المجتمعـات في إنتاج الأفكار التي تعمل على تنظيم حـر اك التجمعات البشرية ـ وتعرف الجامعة بأنها مؤسسة للتعليم العالي تتكون من عدة كليات تنظم در اسات في مختلف المجالات وتخول حق منح درجات جامعيه في هذه الدر اسة.

كما ورد تعريف أخر للجامعة ويقصد بها مؤسسـة للتعليم العـالي تتكون من كليات للفنون الحرة و العلوم و أيضا مدارس مهنية و أخرى للار اسات العليا 'ولها حريـة التصرف في شؤونها ويتمتع أفر ادها بحرية التعليم و المناقتة دون تدخل خارجي ، ويلزم أعضاء هيئة التدريس بها بمستويات علمية و أخلاقية رفيعة ولها سلطة منح الدرجات في مختلف مجالات الدراسـة . كما إن هنالك اتجاهين تناو لا تعريف الجامعة بمنظورين مختلفين و على النحو الآتي : 
ا - الاتجاه الأول : ينظر إلى الجامعة على أنها البيئة الأساسية و المحيط الذي يدرس حالة المجتمع ومشكلاته 'ويعمـل على إيجـاد الحلول و اقتر احها و انطلاقـا مـن هذا فـان الجامعـة توظف الدر اسـات و البحوث بقصد معالجة المشكلات الاجتماعية.

Y- - الاتجـاه الثاني: بركز على الإبعـاد المعرفيـة ويؤكد إن الوظيفـة الأساسية للجامعـة هي عمليـة معرفية بحتة ومن ثم فالتعليم هدف في حد ذاته بغض النظر عن فو ائده وتطبيقاته' وتبقى الجامعة هي المكان الذي تجري فيه الدر اسات و الأبحاث العلمية.

و الجامعة هي تلك المؤسسة العلمية التي تتكون من عدة كليات و أقسـام علمية و إنسـانية ترتبط بوزارة التعليم العالي تتولى تدريس الطلبة وتخريجهم في مختلف الاختصاصسات. وتقوم بمهمة البحث. العلمي ونرتبط بالمجتمع عن طريق مؤسساتها البحثية .

\section{المهور الثاني : العلاقة بين البامهة والمبتهع}

مما لاشك فيه إن من بين أهم وظائف الجامعات هي الاضطلاع بخدمة المجتمع التي تتو اجد فيه بحيث تكون نشاطاتها معبرة عن رغبة هذا المجتمع و اتجاهاته ـ لذا تقع على الجامعات مهمة التفاعل مع الع المجتمع ومتطلباته والتخطيط لتنفيذ هذه المتطلبات وفي المقابل ينتظر من المجتمع ان يؤدي دور ا بارزا في حماية الجامعات و استقر ار ها وتقديم العون لها. وتعد العلاقة بين الجامعة و المجتمع علاقـة تو أمبـه تتداخل خلالها الاستجابات و التأثير، فالجامعة تنولى احتضان وتخريج الكوادر المهنية والعلمية في كافة المجـالات، ويظهر ذلك مـن خـلال نـواتج إيجابيـة تدفع المجتمـع نحو الرخـاء و الرفاهيـة والاسـتقرار الاجتماعي، كما إن الجامعة تضع كل إمكاناتها وطاقاتها خدمة للمجتمع، وفي المقابل تستوحي الجامعة

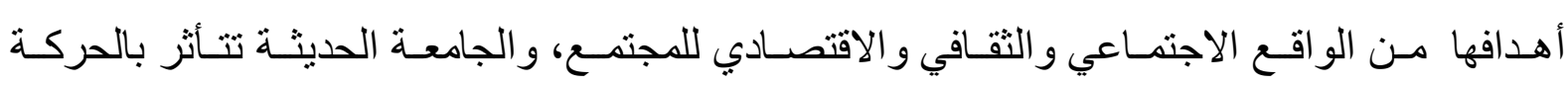
الاجتماعية وتستمد فلسفتها من فلسفة المجتمع وترتبط به ارتباطا وثيقا وصو لا نحو تحقيق أهدافه. ولا يمكن للجامعة أن تعزل نفسها عن المشكلات الاجتماعية، فرسالة الجامعة لا تختص داخل أسوار الجامعة بأعداد الطلبة وتنمية أعضاء هيئة التدريس، لكنها تعبر عن حركة نمو المجتمع، وتسد

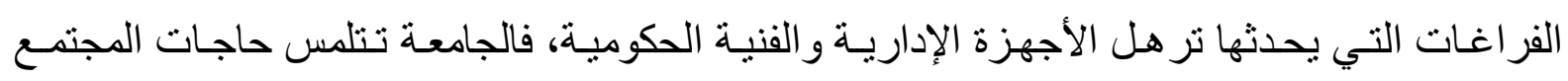
بقطاعاتـه المختلفـة وتقدم الخدمات المختلفـة في أطسار خدمـة التعليم المستمر بتنظيم دور ات تدريبيـة و تطويريـة ومؤتمر ات ونـدوات وورش عمـل للمؤسسـات التعليميـة والأهليـة والاستشــار ات المختلفـة، و إجر اء البحوث و المشاريع المشتركة للمؤسسات و الثركات الخاصة و العامة.

وتتحقق مهمتا خدمة المجتمع وقيادته للأمام من خلال الانتقادات التي توجهها للمجتمع، لاسيما في ظل معطيات المجتمع المعاصر ، وتنامي دور العلم و التكنولوجيا واقتصـاد المعرفة والتركيز على 
المنافسة و الجودة ـ وحتى تؤدي الجامعة دور ها في نقد المجتمع يتطلب ذلك ان تكون على اتصسال بدور معينة في المجتمع ، عن طريق تدريب المو هوبين ومن خلال البحوث العلمية، ويتطلب ذلك استقلال الجامعات ومزيدا مـن الحريـة الأكاديميـة، و المجتمع يحتـاج الى خريجين ليسـوا فقط متخصصين بـل خريجين ناقدين ، لذا فان الجامعات الحديثة ينبغي ان تأخذ على عاتقها تطوير العقل وتحسين إمكانات البشر وتنمية المعرفة من خلال النقد. .

إن الجامعة العصـرية هـي مركز إثـعاع ثقافي للمجتمع، فالجامعـة اليوم هي جامعـة المجتمع، تعيش من أجله وتعمل على رفاهيته ولها دور هام في تذويب الفوارق الطبقبة وذلك من خلال دور هـا التربوي، كما ينبغي على جامعة اليوم أن تفتح أبو ابها لأبنائها من غير طلابها، ليجدو ا في رحابها العلم و الثقافة لتسهم من خلال ذلك في تنشيط بنيته الاجتماعية وذلك عبر التوسـع في إنتـاء مر اكز التعليم المفتوح في الجامعات المختلفة، وذلك باستخدام تقنيات العصر الحديث لتوصيل هذه الخدمات. إن عمل الجامعات على حل مشكلات مجتمعها أصبح يحظى باهتمامـات متز ايدة من جامعات الدول المتقدمة والنامية أيضاوهن هذا المنظور فإن أعضاء هيئة التدريس عليهم أن يندمجو افي حل مشكلات المجتـع، وذلك عن طريق فحص هذه المشكلات في علاقاتها بالموضـوعات الأخرى في مجتمـاتهم المحلية و العمل على تشــيعها والبحث عن حل لها، ويمكن رؤيسة دور الجامعـات في هذا المجال بوضوح من خلال عدة أبعاد وهي التعليم المستمر و البحوث التطبيقيةو الاستشار ات و العمل على نشر العلم و المعرفة بين أبناء المجتمع .

ان إعداد القوى البشرية وتدريبها يعد من أهم وظائف الجامعة في عصر تأكد فيـه ان العنصر البشري هو مصدر الثروة وبقدر أعداده وتنمية معارفه وقدر اته وتطوير مهار اته وخبر اتهه يكون عطلؤه و إنتاجـه ـ. ان التدريس و إعداد القوى البشـرية وظيفة مهمـة من وظـائف الجامعـات في عصدر زاد فيـه الطلب الاجتماعي على التعليم عامة والتعليم الجامعي خاصة ؛ في شتى دول العالم النامي منها و المتقدم على حد سواء، و على قدر جودة الجهد التعليمي في الجامعة تكون جودة مخرجاتها ممثلة في خريجها وما زودوا به من معلومات وخبر ات ومهار ات ـ لكن جودة التدريس في الجامعة ليس عملا قائمـا بذاته

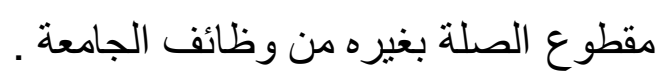
ويعد الكـادر البثـري المؤهـل وبنـاء الثخصـية العلميـة المؤهلـة القـادرة على تحريلك البنـاء الاجتماعي وتوجيهه نحو التنمية الثاملة للمجتمع من أهم الوظائف التي ارتبطت بمهمة التعليم الجامعي، فالجامعـة يقـاس نجاحها بمدى قدرتها على أحداث التغير المخطط لـه المرغوب فيـه نمـو المجتمعح، و الجامعة منذ نشـأتها تفي بأعداد وتخريج الطلبة في كافة التخصصسات التقنية الحديثة المطروحة بين حاجات المجتمع المختلفة . 
ويمكن أن ينظر للجامعة على أنها استثمار في الموارد البشرية على أسـاس أن رأس الهـال

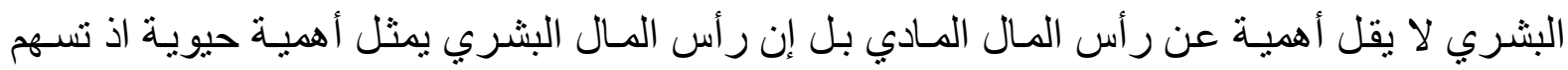

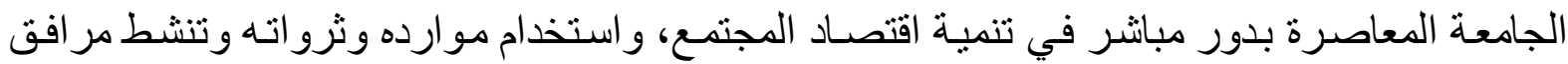

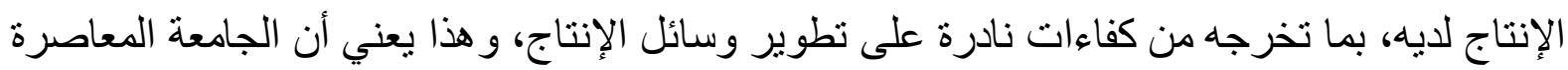

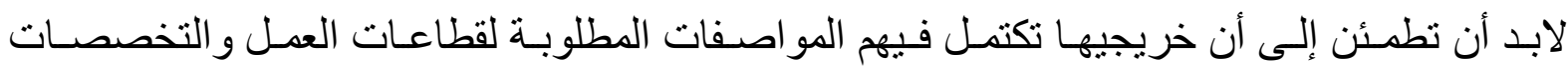

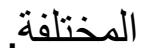

وتعمل الجامعات على إعداد التنصصين و الخبر اءو الفنبين الذين يحتاج إليهم المجتمع في

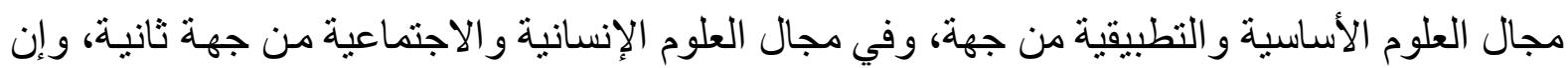

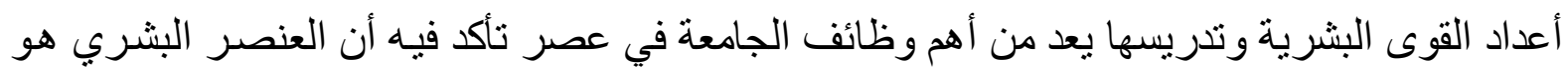
مصدر الثروة، وبقدر أعداده وتنمية معارفه وقدر اته وتطوير مهار اته وخبر اتها ونه يكون عطاؤه و إنتاجه،

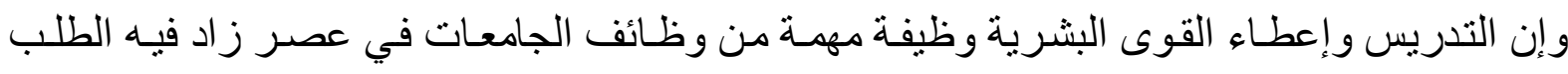

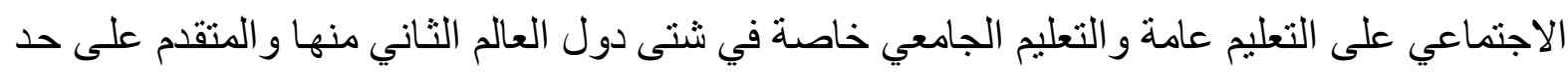

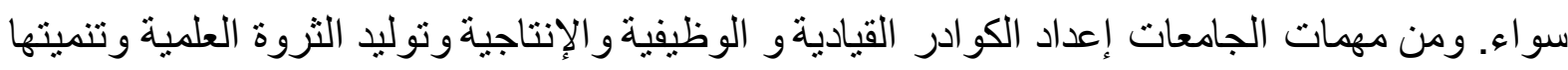
و هذه المهام يمكن أجمالها بالنقاط الآتية:

ا. تحسد الاختصاصـات العليـة والإنسـانية و التكنولوجيـة التي يتـدرب عليهـا الثـباب مـن أبنـاء

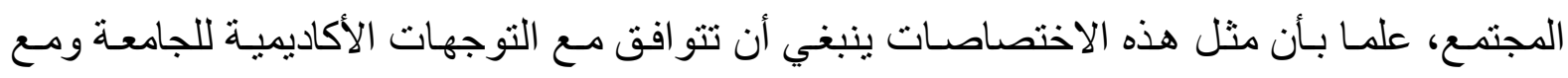
حاجات الدولة و المجتمع إلى مثل هذه الاختصاصات. r. فتح المجال لكافة أبناء المجتمع للتقديم و القبول في الجامعة شريطة أن يكون هؤلاء مؤهلين للقبول فيها. r. تدريب الطلبة كافـة على اكتسـاب الههارات و الخبرات النظريـة و التطبيقية التي تنتلاعم مـع

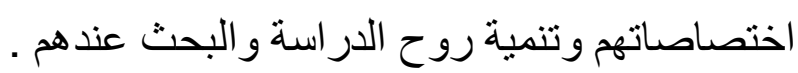

ع. جعل المعرفة الجامعية مستمدة من واقع وظروف ومشكلات المتمع وليست غريبة عنها، كما تشارك في تسريع عملية التنمية ونطوير الحضارة على نحو مبرمج ومدروس. •. مشاركة الجامعة مع الجهات التخطيطية في الدولة و المجتمع في إيجاد منافذ العمل التي يمكن أن ينخرط فيها الخريجون ويخدمون الدولة والمجتمع من خلالها. T. زرع وتتميـة دو افع الدراسـة والتعليم المستمر عند الطلبة لكي يو اصلـوا مسيرتهم الدراسية و البحثية و العلمية بعد تخرجهم. 
ومن خلال هذه المهام العلميـة والتربويـة و التقافية و التنمويـة تسـطيع الجامعـات المشـاركة في

تتمية الموارد البشرية وخدمة المجتمع على أكمل وجه .

\section{المهور الثالث : الجامعهة وتنمية ثقافة المقهوق والمشاركة السياسية}

ان الجامعة العر اقية الحديثة لا تو اجه فقط الانفجار السكاني بل أيضا الانفجار المعرفي ومن هنا

كانت ضـرورة الأخذ بمبدأ التخصص فهنالك كثير من محتويـات المنـاهج التي أصبحت قديمـة ، و إذا عرفنـا ان المعرفة الر اهنـة سـوف تصبح قديمـة أصبح علينـا ان نعد عقلية الطالب بحيث يتعامـل مـع المو اقف و النظريات الجديدة ، وان يعيد تركيب معلوماته وتنظيمها وان يهضم كل جديد بنفسـه ، بمعنى ان ننمي فيه القدرة على التعلم . ملع

لاشك ان إبراز نقافة حقوق الإنسـان والمشـاركة السياسية وتعمبقها في مختلف المجالات من المهام الأساسية التي لابد للمؤسسات التربويـة ان تعمل على ترسيخها ، من خلال تهيئة بيئة ايجابية تسمح للطلبة بالتعبير عن أر اءهم بحريـة. وتعد الجامعات في مقدمة تلك المؤسسـات التربويـة ، و التي يتوقف نجاحها على مدى قدرتها في التأثثر على أفراد المجتمع وفي مقدمتهم الطلاب ، و أعضساء الهيئة الإدارية والهيئة التدريسية العاملين فيها كافة ويمكن ان يكون ذلك من خلال عقد الندوات والحوارات و الفعاليات المختلفة وغير ذلك .

تعرف المشـاركة السياسية على انها : العمليـة التي عن طريقها يؤدي الفرد دور ا في الحيـاة السياسية الاجتماعية لمجتمعة ، فهي تعني إسهام او انشغال الفرد بالمسائل السياسية والمسـاندة الثعبية

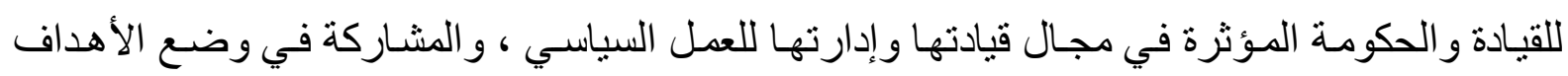
العامة للمجتمع و أفضل الوسائل لتحقيق وانجاز هذه الأهداف وسو اء كان هذا الانشغال عن طريق التأييد و الـرفض أو المقاومـة أو التظـاهر ومـا إلى ذلك ــ و المشـاركة هـدف ووسـيلة فهـي هـدف لان الحيـاة الديمقر اطية السياسية تركز على اشتر الك المو اطنين في مسؤوليات التفكير و العمل من اجل مجتمعاتهم ، و هي وسـيلة لأنه عـن طريت مجـالات المشـاركة يتذوق النساس أهميتها ويمارسون طرقها و أسـاليبها وتتأصل فيهم عاداتها ومسالكها وتصبح جز عا من ثقافتهم وسلوكهم .

و المشاركة السياسية مبدأ ديمقر اطي من أهم مبادئ الدول الحديثة ، مبدأ يمكننا ان نميز في ضـوئه الأنظمـة الديمقر اطيـة التـي تقوم على المواطنـة و المسـاو اة في الحقوق و الو اجبـات مـن الأنظمـة

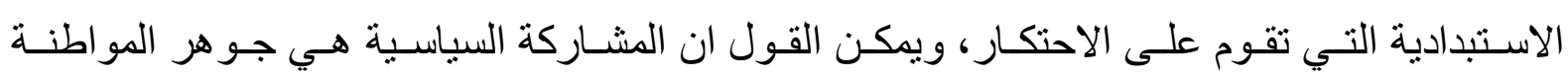
فالمو اطنون هم أصحاب حقوق اجنماعية واقتصادية وثقافية وسياسية يصونها الدستور الذي يعبر عن هذا بكل المواد التي تتعلق بحقوق المواطن، و الفرد لا يستطيع ان بشـارك سياسيا الا إذا انه مو اطن كامل غير منقوص الحقوق ومن حقه ان يمارس حقوقه داخل وطنه . 
وبعبـارة أخرى ان المشـاركة السياسية هي التعبيـر العملي عن العقد الاجتمـاعي ، ويمكن

القول ان المشاركة السياسية هي جو هر المواطنة وحقيقتها العملية وهي التي تحدد الفارق النوعي بين الر عايا و المو اطنين وبين الامتياز ات و الحقوق ، ذوو الامتياز ات في كل عصر وفي كل نظام لم يكونوا مو اطنين بل رعايا وذوو الامتياز ات اليوم ليسوا مو اطنين بل هم رعايا ومو الون فمن يضن نفسه سبدا على جماعة من العبيد هو أكثر منهم عبودية وذو الامتيازات اليوم ليسواوطنيين ، لان الوطنية تتنافى مع الامتياز ات على طول الخط .

وتجدر الملاحظة ان مفهوم المشاركة السياسية مفهوم حديث و افد على الثقافة العربية و على

الفكر السياسي خاصة ولم يتوطن بعد اي ان الثقافة العربية لم تتمثنل هذا المفهوم ومـا يتصل بـه من المفاهيم الحديثة وتعيد إنتاجها وفق المعطيات الوقع وحاجات المجتمع ، بل ان جل ما فعلته حتى يومنـا هذا هو غمس هذه المفاهيم في مستنقع التقليد ومحاولة تكييفها مـع التراث او إعادة إنتاجها فيهـ . مما يؤدي إلى الحد من القدرة التنويرية و التحررية و التوليدية و الإجر ائية لهذه المفاهيم . وتقاس المساهمة السياسية للمو اطن بمعايير واضحة تتعلق بقرته السياسية على التعبير عن أر ائه بحريـة وبترجمة قناعاتـه السياسية وتجسيدها خـلال العمل الفردي او الجماعي المنظم وبدرجـة تأثثيره على آليات عمل النظام السياسي وقراراته وتحكمه بسلوك ممثليه، فبمقدار مـا يمتلك المواطن الوعي السياسي والأدوات و الوسائل التي تتيح لله ترجمة هذا الوعي في سلوك حر بعيد عن الإكر اه،

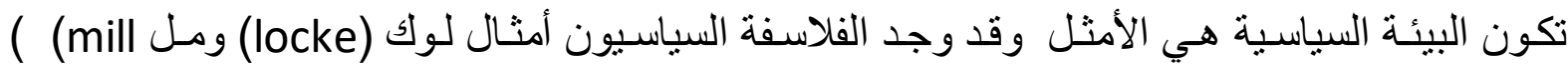
وتوكفيل (Tocqueville) و غير هم ان هذه المعـايير هي أساسية لنظـام ديمقر اطي نـاجح قائم على التعددية وحرية التعبير وحقوق الأقليات .

ان التربية على حقوق الإنسان تمتلك درجة كبيرة من الأهمية، حيث تسـاهم بشكل رئيسي في تعزيز قيم التسـامح و العدالة في المجتمع وفي كل مؤسسـاته جنبا الى جنب مـع كل مؤسسات التثقيف و التعليم في المجتمـع ، ويمكن القول ان تعليم حقوق الإنسـان لبس موضو عا تعليمبـا بـالمعنى الحرفي للكلمة ، بل هو فهم الموضوعات و الظو اهر المحيطة بنا من خلال التعلم عن حقوقنا و إدر الك الواجبات الناتجة مباثرة عن تلك الحقوق ، لذلك فان حقوق الإنسان يمكن تضمينها في اي موضوع تعليمي بحيث تصبح جزءا من جو المدرسة والجامعة و المجتمع ومن ثم الدولة، اذ ان تعليم حقوق الإنسـان بسـاعد ولا سيما صغار السن على فهم و إدر الك دور هم كمو اطنين في مجتمع ديمقر اطي. ان الانفتاح الكامل على مو اد التعليم الإنسـاني يعزز مفـاهيم حقوق الإنسـان ويثبـ مرتكز ات الخصوصـية الحضـارية و الثقافيـة التي تـدعم بقوة روحيـة الانتمـاء إلى المجتمـع و الـوطن و الأرض 
و التراث، ويعتبر هذه الخصوصية وجها من الأصـالة يمكنها ان تتطور بالاستفادة من الآخرين وليس بالتعنت و التزمت .

و تقوم المؤسسات التعليمية بدور مهم في التنمية السياسية لكل مرحلة من المر احل العمرية للفرد فالأسرة و الزملاء و المدرسـة و الجامعة جهات تقوم بتزويد الفرد بجزء مهم من مفـاهيم المجتمع الذي ينتمي إليه وقيمه و عاداته ومعتقداته ـ وفي هذا الصدد يشير جان جالك روسو إلى الوظيفة التعليمية فيما يتعلق بالتنميـة السياسـية لإفـر اد المجتــع ودور التعليم في تنميـة التصـرفات المسـولة للفـرد و إدر اكـهـ للصالح العام ومشاركته في اتخاذ القرار ات السياسية الأمر الذي يحقق قدر ا من المساو اة الاجتماعية بين الإفر اد بحيث لا تظهر الفوارق التي تعيق تحقيق المسـاو اة السياسية مما يعزز لدى المواطنين الانتماء

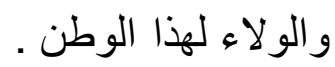

كمـا يعد التعليم العـالي احد الركائز الأساسية للتنميـة السياسـية في المجتمعـات ، ويعد الأداة الفعالة في نقل القيم و المعارف المختلفة للطلبة وتجعله عناصر فعالة في المجتمع الذي ينتمون إليه . و على الرغم من ان التعليم في العـادة يهدف الى تطوير المعرفة لكن التعليم الذي نحن بصدده يجب بالضرورة ان يساعد على تطوير نسق من القيم والمهار ات لدى الأفر اد المستهدفين، بحيث يؤدي هذا النوع من التعليم في المحصلة النهائية الى توفير بيئة ملائمة ونموذجية، حيث تؤخذ حقوق الإنسان جديا و تكون مضمونة وحاضرة في كل طريقة تدريسية وفي كل علاقة قائمة.

ان الديمقر اطية و المشاركة الثعبية ومساهمة المو اطن في حكم نفسه وتقرير مصبره إنها أفكار ذات معـاني سـامية وتمثل أعلى درجـات الارتقاء عندما يـمكن الفرد مـن الثـعور الذاتي بحكم نفسـه وقدرته على الانصياع الى أسس العقلانية وو اجباتها؛ كما ان الفرد لا يأتي الى هذه الحياة قادرا على حكم نفسه و إنما يبدأ تدريبه على الحكم الذاتي منذ طفولته. و هذا لا يتم بين ليلة وضحاها و إنما هو نتيجة سنو ات طو ال على التدريب و المعايثة منذ البدايات الأولى للطفولة المبكرة. وتعد الإدارة الجامعيـة التي تتولى مهمة تسيير شؤون مؤسسات التعليم العالي وتطوير نظام العمل فيها إحدى الوسـائل المهمة التي تعمل على توفير المناخ المناسب لتتم العملية التعليمية فيها بشكل يضمن إحداث تنمية حقيقية في جميع المجالات .

إن دور الإدارة الجامعيـة متـداخل مـع ادوار التعلـيم العـالي فـلا يمكن الحـديث عـن المنــاهج الجامعيـة بمنـأى عن دور الإدارة الجامعيـة في تصـميم المنـاهج وتطوير هـا وتعديلها وفق احتياجـات المجتمع وليس من المنطق الحديث عن الهيئة التدريسية بمعزل عن الإدارة الجامعية فهي التي تمنحهم الصلاحيات التي تساعدهم في تحقيق التنمية السياسية للطلبة جنبا إلى جنب مع التأهيل العلمي اللازم في 
مختلف التخصصات، و الدعوة إلى ممارسة الأنثطة التي من شأنها تنمية الطلبة سياسيا وتعزيز الهويـة الوطنية لديهم وزيادة مشاركتهم السياسية في سائر القضايا الوطنية التي تهم المجتمع .

فالجامعـة بمـا تضـم مـن طاقـات علميـة وثقافيـة ومر اكز بحـث معنبـة ينبغي أعـادة النظر بكل

مفاصلها الإدارية والتربوية والعلمية بتفكيك عناصر الأزمات والدخول إلى صلبها بمنهجية واستر اتيجية تعتمد أو لا على علمائها ومفكريها و على أقسامها الاجتماعية والإنسانية في بحوث ودر اسات نقدية، و هذا لا يتأتى الا بتو افر شروط البحث في الحريـة وارتفاع مستوى الوعي والإدر الك في المشـاركة الحيوية، لدى القيادات الإدارية و العلمية في الجامعة بالخروج من ضيق الأفق والخوف من تعدد الآراء النقدية. إن التطور ات التي يشهدها العراق منذ العام ب . . rوحتى ألان جديرة بان تقع الجامعة في عمق تحولاتها ، بنشر ثقافة حقوق الإنسـان وحقوق الطلبة على وجها التخصيص و هي كثيرة ومهمة جدا ، وتقع ضمن أولويـات الانتقال لعر اق جديد ، وثقافة المجتمع المدني و التعدد التقافي و الفكري و الديني و القومي و القبول بالر أي الأخر و إثناعة ثقافة المو اطنة و النقد والحوار و استخدام المعرفة لتوسيع الحريـة الإنسانية ودعم العدالة الاجتماعية .

فالجامعات تقوم بدور كبير في المجتمع ، فهي المنظمـة التي يثـعر منسبيها بالحريـة العلميـة و الضمان و الأمان و الاحتر ام و هي المنظمة التي يحيا فيها الطلاب حياة تقدمية نتيجة لجهودهم وبتأثير الحرية و الانفتاح و الديمقر اطية التي يعيشون في ضـلالها تلك الصفات التي تعتبر من مبادئ المنظمـة الجامعية في العالم التقدمي، فالطلاب الذين لا بمارسون الديمقر اطية الصحيحة في جامعاتهم لا يحملون ولاء للنظام الديمقر اطي .

\section{المور الرابع: دور الجاهعة في عملية تنمية الموارد البشرية}

ان المفهوم الثـامل للتنمية يؤكد على إنها العملية المجتمعية الموجهة نحو إيجاد تحولات في البناء الاقتصادي و الاجتماعي ، ويحضى التعليم الجامعي بدور متميز في مؤشرات التنمية لكونه إحدى الحاجات الأساسية التي تحققها التنمية. ويقصد بالتنمية الاقتصادية والاجتماعية بأنها النمو والتغير الذي تتكامل فيه جميع أوجه النشاط الاقتصادي و الاجتماعي ، و تتضمن كافة الإجر اءات و الوسائل و الأساليب التي تتخذ لزيادة الإنتاج من الموارد الاقتصـادية المتاحة و الكافية لرفع مستوى معيثـة الفرد والمجتمع مـع تنظيم عمليـات التنميـة بشكل يحقق الكفايـة و العـدل ويحقق أحسـن اسـتخدام للمـوارد الاقتصـادية 
و التنمية الحقيقيـة لا تقتصـر على جانب دون أخر فهي تنمية مقصودة يعبر عنها في أدبيـات التنمية بالتنمية الثناملة في جو انبها الاقتصادية و الاجتماعية وما تتضمنه من محاور و عناصر عديدة تشمل الصحة و التعليم و العمل و الاخل الكافي وإثباع الحاجات الأساسية والقدرة على العطاء و الإبداع .

أي ان تحقيق تقدم في أي مـن المجالات الاقتصسادية والاجتماعية يعزز فرص التقدم في بقيـة المجالات ، ويعزز فرص تحقيق أفاق أرحب ومستويات أفضل للحياة وهذا الأمر يوضـح أهمية تكامل التنمية الاقتصادية والاجتماعية والسياسية والإدارية لضمان جني أفضل الثمار المختلفة لعملية التتمية في ضوء المو ارد المتاحة ـ و التنمية الثاملة والتعليم الجامعي كلاهما يلتقيان في الإنسان بوصفه محورا لهما ، فالتعليم الجامعي يتناول شخصية الإنسان بجميع جو انبها وتحقيق التكامل لها . و التنمية تتناول المجتمع من جميع جوانبه وتسعى ان تتيح له التقدم ، والتنمية الثـاملة لا تكون فعالة من غير جهود التعليم العالي في تنمية الثروة البشرية للنهوض بمتطلبات التنمية ، وذلك كون ان التنمية الثاملة للجو انب الاقتصادية و الاجنماعية و الثقافية و السياسية و الروحية في المجنمع هي الصبغة

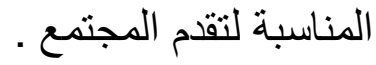
وتعد الجامعة من أهم المصـادر المسئولة عن عملية التنمية الاقتصـادية و الاجتماعية للمجتمع نظر اللمهام التنموية والنهضوية التي نؤديها وسط المجتمع و التي من شأنها أن تحقق التغير الاجتماعي بصنفيه المادي و غير المادي ـ ولعل من أهم المظاهر التنموية الاقتصادية التي تؤديها الجامعة للمجتمع، مساهمتها الفاعلة في توسع المدينة عموديا و أفقيا ، ونمو سكانها وزيادة نشـاطهم الخاص و العام فضلا عن أهمية الجامعة في رفد المجتمع بالملاكات البشرية المؤهلة علميـا و المدربـة تقنيا التي تسـتطيع المساهمة في عملية البناء وإعادة البناء الحضاري للمجتمع .

كذلك يجب القول أن الجامعة تؤدي الدور الفاعل في رفع المستوى المعيشي للمو اطنين طالما أنها مصدر من مصادر الطلب على السلع و الخدمات و أنها أساس القوى العاملة المدربة هذه القوى التي تشارك في زيادة الإنتاج وتحسين نوعية الخدمات مما يترك أثره الفاعل في ارتفاع المستوى المعيثي لسكان المدينة التي توجد فيها الجامعة، كذلك تساهم الجامعة في نمو وانتشـار الخدمات الاجنماعية التي تحتاجها المدينة كالخدمات السكنية و الصحية و التربوية والتعليمية و الترويحية إذ أن الجامعة تعد بمثابة العامل الجاذب للسكان، و السكان لا يمكن أن يبقو افي المدينة الجامعيـة بدون خدمات، لذا لابد من بناء وتوسيع الخدمات على اختلاف أنو اعها، الجامعة تشبع هذه الخدمات و الطلب المتز ايد عليها من لدن السكان، لذا الجامعة تشارك مشاركة فعالة في تنمية وتطوير الخدمات التي يحتاجها السكان. 
وقد حققت الجامعات تأثير ا كبير ا في تطور المدن وتوسعها ، ممـا أدى إلى ارتفاع درجات

تحضر المؤسسـات وتكاملها وتجمـع المؤسسـات المتشــابهة في منـاطق معينـة داخل المنطقة المركزيـة

فتظهر آنذاك مناطق خاصـة للمحلات التجارية و أخرى متخصصـة بالأمساكن الترفيهية وأخرى خاصـة بالمؤسسات الحكومية. وللجامعات تأثير فعال في عملية تنظيم شوارع المدن ووسائل النقل ، حيث تعد الثو ارع و الطرق ملكية عامة للسكان وللجميع الحق باستخدامها و الانتفاع منها وتحمل مسؤولية إدامتها بصورة مشتركة، إضافة إلى دور الجامعات في زيادة عدد المناطق السكنية التي يقيم فيها التدريسيين و الطلبـة وبقيـة المـوظفين الذين يعملون في الجامعـة بصـورة مباشـرة وغير مباشـرة، ناهيك عـن دور الجامعـة في زيـادة عـدد الأبنيـة و العمـار ات المتخصصــة للأنشــة الخدميـة التـي تحتاجهـا الجامعـة كالمصارف وشركات التأميم و المصـانع و المحلات التجاريـة و المؤسسـات الخدمية و الترويحية كل هذه المنشئات الإنتاجية و الخدمية والترويحية التي تحتاجها الجامعة تؤدي إلى توسع المدينة التي توجد فيها الجامعة. ويكون دور الجامعة في التنمية الاقتصادية والاجتماعيـة تزويد المجتمع بـالكثير من الخبرات و المهار ات الفنية والإدارية لدفع عجلة التنمية الاقتصادية وتنشيط خططها و القيام بـالبحوث و الدر اسـات التي تهدف إيجاد الحلول لمختلف المشكلات التي تقف في سبيل النمو الاقتصادي و الاجتماعي وترسيخ النظم و القيم و المعـايير و الاتجاهـات اللازمـة لتشـجيع التقدم. وقد ظهرت أهميـة التعليم الجـامعي مـن المنظور الاقتصادي من خلال الدر اسات والأبحاث التي ربطت بين دور التعليم الفعال وبين جملة من مظاهر الحبـاة العصرية والجهود في تبرير الإنفاق المتزايد على التعليم وجوانبـه المختلفة ، ومن الجو انب التي ظهر للتعليم فيها إسهام ملحوظ في التنمية الثاملة وذلك من خلال ما يأتي: ا - تحسين نوعية السكان ورفع نوعية ودقة العمل وكفايتها .

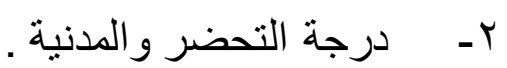

r- - زيادة نسبة مشاركة المر أة في قوة العمل وكفاءتها وترشيد السلوك للفرد. ع - تحقيق النمو و التطور الاقتصادي .

و فيمـا يلي عرض إلى أهم المجالات التنمويـة والتربويـة التي تؤديهـا الجامعـة وتسـاعد على وجودها داخل المجتمع هي :

\section{ا - دور الجامعة في النشاط الثقافي والفكري:}

تقوم الجامعة بنشر الثقافة بكل أنو اعها للر اغبين فيها و المحتاجين إليها من أبناء المجتمع بغض النظر عن أعمـالهم و أعمـار هم، ومـن ثم تمكنهم مـن حل مشكلاتهم و التكيف مـع مجتمعهم وتزيــ مـن قدرتهم على أحداث التنمية المنشودة كما تقدم لطلابها بر امج ثقافية ترفع مستو اهم الثقافي، وتربطهم 
بييئتهم ومجتمعهم، لذا لا يقتصر دور الجامعة على نقل وتوصيل الرصيد الثقافي من و إلى الجامعة أو

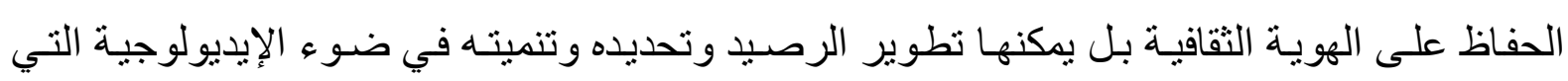
يتبناها المجتمع، مستعينة في إحداث ذلك بعلومها وأنشطتها و آلباتها، وكل إمكاناتها المادية و البشرية. إن الآليات و الوسائل التي تؤدي بها الجامعة وظائفها المتعلقة بالتنمية وهي:

أو لا: ربط المـادة العلميـة بالإنسـان و المجتمـع و الحياة و البيئة، بدلا مـن تدريس المـادة العلميـة بأسـلوب تجريدي يعزلها عن كل شيء، الأمر الذي يجعل المادة العلميـة ضئيلة التأثثر في الطالب. ثانيا: العنايـة باية الكبيرة بالإرشـاد ور عايـة الطلبـة خلقيـا و عقليـا وقيميـا في قاعـة المحاضـرة وخارجها بو اسـطة لجـان الإرشاد.

ثالثا: الإكثار من إقامة الندوات و النشاطات اللا صفية و المؤتمر ات بسهم فيها الأساتذة و الطلبة جنبا إلى جنب، وكلها تدور حول مشكلات المجتمع والبيئة المحلية والعالمية. رابعا: المشـاركة الفعالـة للأسـاتذة في أنشطة وسـائل الإعلام الصـحافة، القنوات الفضـائية، الإذاعـات المسمو عة، أنشطة منظمات المجتمع المدني، و المؤسسات الرسمية .

ان دور الجامعة في التوعية والتتقيف يهدف أساسـا الى تعميق القابلية للتعليم ، و إقرار القيم التي تؤكد اعتزاز الإنسان بالنز اهة والصدق و الأمانة و التشبث بالوطن و الاعتز از بالانتماء إلبه و العمل

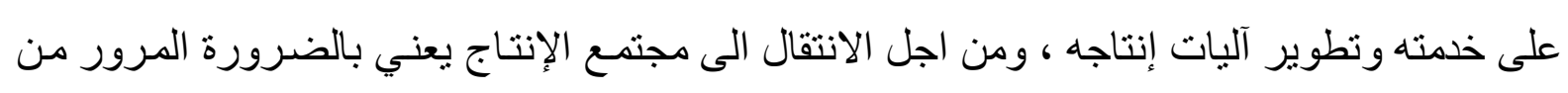

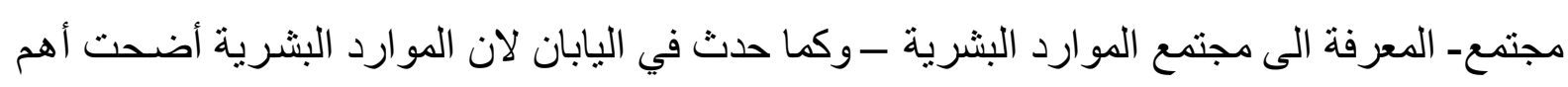
الموارد الأولية فر أس المال غير ذي قيمة دون موارد بشرية واعية بدور ها التاريخي . إن نشر العلم و الثقافة من الأدوار الطبيعية للجامعة في الوقت الذي نعيشـه للنهوض بـالمجتمع وذلك لان الجامعة مركز إثـعاع ثقافي للمجتمع تتعرف من خلاله على مشكلاته، وتعمل جاهدة على إيجاد الحلول المناسبة له، ولا يقتصر دور الجامعة في التنشيط التقافي والفكري للمجتمع الخارجي ، بلـ لابد ان يشمل مجتمع الطلاب فيها وذلك من اجل التوجيه الاجتمـاعي و الفكري وتوجيه الثباب خلقيا

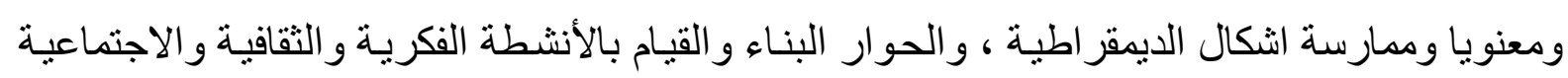

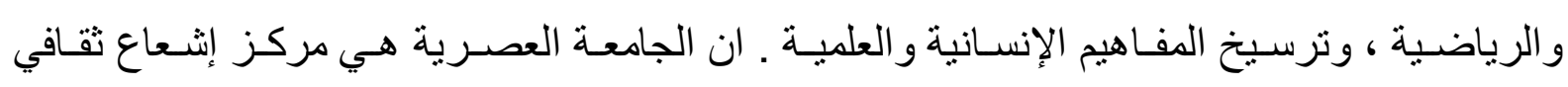
للمجتمع برمته ، كونها أصبحت اليوم جامعة المجتمع تعيش من اجله وتعمل على رفاهيته ، ولها دور هام في تذويب الفوارق الطبقية وذلك من خلال دور ها التربوي ، كما ينبغي على جامعة اليوم ان تفتح أبو ابها لأبنائها من غير طلابها ، ليجدوا في رحابها العلم والثقافة ، لتسهم من خلال ذلك في تنشيط بنيته 
الاجتماعية وذلك عبر التوسع في إنشـاء مر اكز التعليم المفتوح في الجامعات المختلفة وذلك باستخدام تقنيات العصر الحديث لتوصيل هذه الخدمات .

وتؤدي الجامعـة اليوم وظـائف كثيـرة فاعلـة وحيويـة في حركة المجتمـع العصـري إذ تشـكل مختبر ات للفحص، و الاجتهاد العلمي، و التعبير الفكري، و المناظرة الثقافية، والبحث عن الحقيقة، والعمل على تحديث المجتمع، وربط الجسور بين الإنسان المتعلم والمجتمع فالجامعة لم تعد محصورة في أطسار العمل الأكاديمي فحسب بل بدأت تساهم في شكل فعال في عملية البناء و التنمية، و نقل المجتمعات من التبعيـة الفكريـة إلىى مرحلـة النهوض و الاسـتقلالية فتقوم بـأدو ار كثيرة عن طريـق كو ادر هـا وقياداتهـا

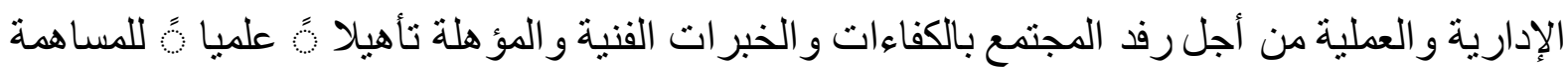
في حركة التنمية و التحديث.

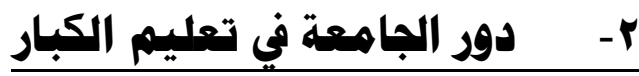

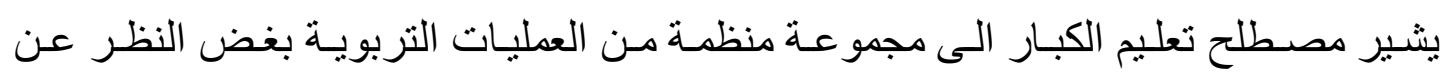
محتو اهـا او مسـتو اها ، سواء كانـت نظاميـة ام لا ، وبصـرف النظـر عمـا اذا كانـت تطيل فترة التعليم الأولى او تحل محله في المدارس والجامعات وفي أماكن التلمذة الصناعية حيث ينمي الأفراد الذين يعتبر هم المجتمع كبار ا قدر اتهم ويثيرون معارفهم ، ويحسنون مؤ هلاتهم الفنية و المهنية ، او يحولون اتجاهـا لوجهـة جديدة ، ممـا يحدث تغير ات في اتجاهـاتهم او سـوكهم عـن طريـق التنميـة الثخصية و المشاركة في التنمية الثقافية و الاقتصادية و الاجتماعية المستقلة والمتو ازنة . .

وينظر إليه بعضـهم على ( انهـ كل خبرة تعليمية تقدم للكبار بصرف النظر عن مضمونها او محتواها أو الطريقة المستخدمة التي تقوم عليها او تقوم بها ، وبهذا يعد ميدان تعليم الكبار ميدانا واسعا عريضا يشتمل قطاعات مختلفة من البشر في مختلف ميادين العمل و الإنتاج ، ويعد أيضـا ميدانا متعددا يرتكز في أساسياته على فكرة التربية لعالم متغير ، وانـه تعلم غير منتهِ لسن معينـة أو بر امج معينة او سنو ات در اسية معينة) .

ويقوم تعليم الكبار في أساسه على فكرة التربية المستمرة والتعليم مدى الحياة وينظر إليه على نحو عام أنه التعليم الهادف المنظم الذي يقدم للبالغين أو الر اثدين أو الكبار غير المقيدين في جامعات

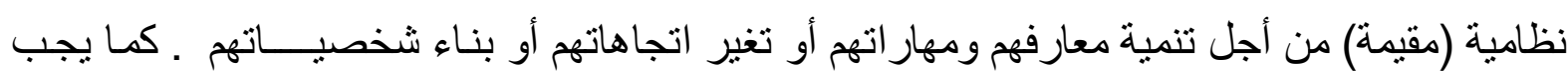
ان ينظر إلى التعليم الموجه للصغار او الكبار باعتباره جزءا من التعليم المستمر مدى الحياة الذي يعمل في إطار حضاري بوضع في إطار مجتمعي ، يولد ثقافة تؤثر على عمل التعليم في مدخلاته ومخرجاته المتأثرة بدور ها بطموحات و احباطات المجتمع ، و أهدافه التنموية ، بل وفي رؤيته ووجهة نظره في

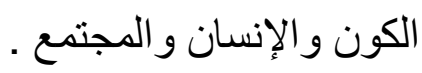


وتؤدي الجامعات دورا هاما في إطار العديد من مجالات تعليم الكبار ومنها محو الأمية ، حيث تلعب الجامعة دور متعدد الإبعاد سو اء بر امج المكافحة او بر امج المتابعة . وفي مجال مو اصلة التعليم فأن هنالك فئة من الكبار حصلت على قدر من التعليم ثم انقطعت لأسباب اقتصـادية او اجتماعية ، او تربوية وغير هاوبعد فترةز الت الأسباب في هذا الإطـار يقدم تعليم الكبار من خلال مؤسسـات التعليم

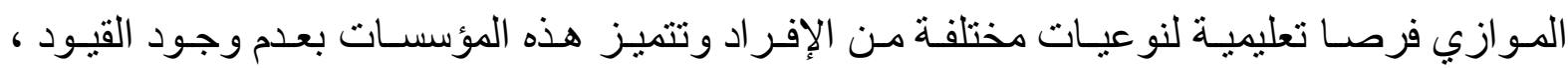
و الضو ابط المتشددة الموجودة في مؤسسات التعليم النظامي مثل شرط السن وتوقيت الدر اسـة و غير هـا مما يتيح للدارس حرية الحركة . وتسـهم الجامعات في مسـاعدة الإفر اد على مو اصلة تعليمهم الجامعي من خلال قبول الطلاب ببعض الكليات الجامعية (نظام الانتساب) وتقديم بر امج التعليم الجامعي المفتوح و التعليم عن بعد.

وقد يبدو ان مفهوم التعليم المستمر يعني في بعض الحالات التعليم المهني او التدريب على مهار ات معينة او قد بعني تعليم الكبار او محو الأمية غير انه يشتمل في حقيقة الأمر انظمهاه وميادين متعددة ويتطلب تغييرات في بنية النظام التعليمي النمطي او التقليدي المألوف و عليه فان التعليم المستمر بمفهومه الثائع يعني ان التعليم لا ينتهي بانتهاء الفرد في مرحلة تعليمية معينـة سواء كانت المرحلة الابتدائية او الإعدادية او العالية وإنما بيتمر باستمرار الحياة وفي سياقها.

\section{r- دور الجامهة في الاستشارات والبهرث التطبيقية}

تمثل البداية الأولى لانفتاح الجامعة نحو المجتمع ، اذ بدأت في تقديم خدماتها وحسب معطيات القانون رقم (ع 7) لسنة 9V9 ( ، الذي أناح قيام مكاتب استشارية هندسية ، وتوسعت بعدها لتشمل قيام مكاتب استشارية زر اعية وبيطرية و عيادات طبية استشارية و عيادات طب الأسنان و غير ها ، و انطلاقا من مقررات الدولة وسعيا من الجامعة لتطوير وتوسيع خدماتها الى حقل العمل فقد قامت اغلب كليات الجامعات العر اقية بفتح مكاتب استشـارية وعلمبة تقدم خدماتها من خلال الخبر ات المتخصصـة التي تمتلكهـا الجامعـات ، وبمـا يسـاعد على تجـاوز المشكلات التـي تو اجهها مؤسسـات حقل العمل وتنفيذ و اجباتها على أكمل وجه.

و الجامعة تعد بيت خبرة للاستشـار ات و المساعدة و تقديم المعرفة و الخبر ات المتنوعة استنادا الى قدر اتها العلمية وخبر اتها المعرفية ومواردها البشرية المؤهلة ، وتوظيف هذه القدر ات في مجالاتها التطبيقية المتنوعة من خلال إرساء علاقات التعـاون وربط الجامعة بالوحدات الإنتاجية في مجالات الصـناعة و الزر اعـة وقطـاع الإعمـال إضـافة الحى القطاعـات الخدميـة وحمايـة المستهلكين ومؤسسـات المجتمع المدني . 
وتعد البحوث التطبيقية بحوث عملية تقوم على تطبيق واستثمار وتطوير نتائج البحوث الأساسية وتستهدف خدمة الإنسان ورفاهيته ، كما انها بحوث توجه مباشرة لحل مشكلات المجتمع المحلي في مجال الإنتاج و الخدمات و المشكلات الاجتماعيـة ، ومثنل هذه البحوث غالبـا مـا تسفر عن تجديدات و ابتكـار ات تقضـي على المشكلات وتـؤدي بالتـالي الى توثيـق العلاقـات بـين الجامعـات ومؤسسـات

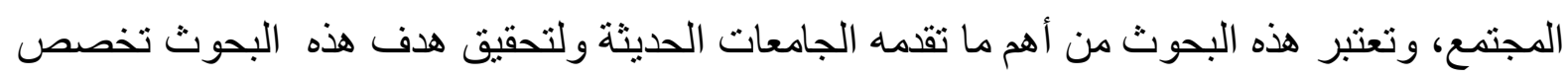
بعض الجامعات مكتب اتصـال خـاص بها يذهب ممثلوه الى الجهات المختلفـة للحصـول على عقود للأبحاث، وفي جامعات أخرى تخصص الجامعة جزءا من أرضها للشركات الصناعية لكي تقيم كل شركه راغبة مركز أبحاث خاص بها على ارض الجامعة، يعمل فيها أساتذة الجامعة لتقديم البحوث التي

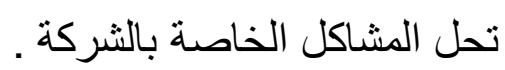

و هناك بعض الأساليب التي تساعد الجامعة في القيام بدور ها في التنمية الاقتصسادية، ومن أهم هذه الأساليب الثر اكة بين الجامعة و المؤسسات الصناعية والتجارية في المجتمع حيث تسعى العديد من الجامعـات إلى تقويـة العلاقة بينها وبـين تلك المؤسسـات، و هنـاك حاجـة إلى إقامـة مثنل هذه الثـر اكة خصوصا مع تعقد المعرفة وتز ايد حجم المنافسة و التغير السريع و المستمر في كافة المجالات ــ ويمكن إقامـة مثنل هذه الثـر اكة بـين الجامعـات وقطاعـات الأعمـال بأثـكال مختلفة مثنل مشـرو عات الطـلاب المرتكزة إلى المجالات الصناعية والتجاريـة المتنوعة، او تمثيل رجل الأعمال في الجهاز الأكاديمي، و الجامعـة في حاجـة إلى مثنل هذه الثـر اكة مـع هذه القطاعـات لفهم التغير ات المسـتمرة و المهـار ات المطلوب إكسابها لطلاب الجامعة، و الى الحصول على التخذية المرتدة عن أداء الطلاب وخاصـة فيما يتعلق بمهار اتهم ، ومن ثم إحداث التغييرات المطلوبة في المناهج واستر اتيجيات التدريس ولذا يجب ان تصبح مؤسسات التعليم العالي كمر اكز تعلم لإحداث التكامل الصحيح بين الدر اسـة النظرية و المهار ات العملية. . ولكن من الإنصاف القول إن الجامعة لا تتفرد وحدها بهذه الوظائف، بل تسهم معها كثير من المؤسسات الاجتماعية الأخرى في تحقيق النمو، من ذللك إسـهام أربـاب التعليم الفني المتوسطو العمال المهرة، ولكن الجامعة أيضا هي التي تعد المعلمين الذين يعدون بدور هم هذه الفئات، كذللك تسـهم مر اكز البحث العلمي ووحداته في النهوض بدور بحث المشكلات التي تواجه المجتمع، و إن كل ذلك يتم في كثير من الأحيان بالتعاون مع رجال الجامعة ؛ كما لا ينبخي ان ننكر دور المؤسسات الأخرى في وظيفة التو عية الوطنية للنمو، من ذلك الأسرة و المدرسة و المسجد و الصحافة و الإذاعة ومـا الى ذلك، وكان من شـأن إسـهام التعليم في الحيـاة الاقتصـادية للمجتمعـات أن ظهرت فروع مـن المعرفـة الاقتصـادية تهنم 
بدر اسة (اقتصاديات التعليم) و اقتصـاديات القوى او الموارد البشرية بحيث أصبح ما ينفق على التعليم من المال العام لا يدخل ضمن الخدمات و إنما ضمن مقررات الاستثمار. و على هذا النحو فان الجامعة لا تتمسك فقط بدور ها في عملية التنمية بل تؤكد على جدارتها به، وحيوية علاقتها المجتمعية بعملية التنمية. كما يساعدها ذلك على التخلص من سلبيات بعض الرؤى القاصرة التي لا ترى في الجامعات إلا العبء المالي على الحكومة، وكمجال للإنفاق يفتقر إلى عائد او

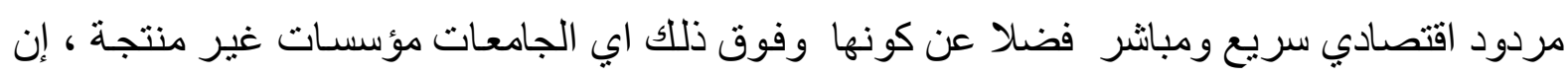
معالم ومجالات الدور الجامعي في خدمـة المجتمع إنمـا تجيء شـاملة لأدو ار هـا الثلاثة : التعليم والبحث العلمي وخدمة المجتمع ومرتبطة بها ارتباطا وثيقا . فالتدريس و التعليم الخلاق يعتمد أساسا على البحث

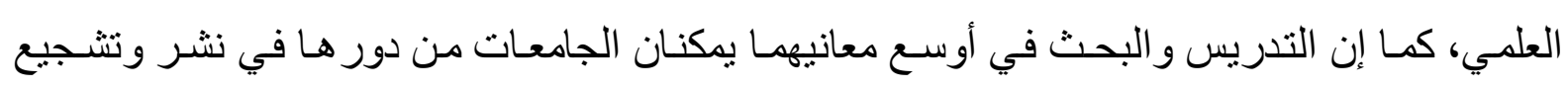
وتعميم الاتجاهات الاجتماعية والقيم الإنسانية المرغوبـة، التي تمكن من النهوض بالإنسان الى أعلى ملكاته ومؤ هلاته الطبيعية و المادية ، فتكون بذلك قادرة على تخريج المواطن القادر على فهم مجتمعه؛ و ارتباطه بالمجتمعات الأخرى وحل مشكلات التنمية، و الإسـهام في بناء مجتمع عصري وقيادته نحو التقدم والازدهار ، وتلك في مجملها أهداف تسهم في النهوض بالاقتصساد القومي في مجمو عه ، وتدعيم تيار التنمية الثاملة في البلاد .

و الجامعات العصرية لا تقتصر أدو ار ها على تنمية النظم الاقتصـادية و السياسية والإنتاجية في العالم المعاصر فقط، بل هي ضمير المجتمع وهي عامل مهم في تقلم النقافة الإنسانية وهو مـا يعلي من قدر ادوار الجامعـات العصدرية كمكان لاستخر اج الأفكار الجديدة و الحكمـة وهي الوظيفة الأكثر عمقا للجامعات، ودور الجامعات في نقد المجتمع يسهم في التوجيه القيمي والتكامل القيمي و الكمال الروحي، و الانتقاد هو تحرير عقول الناس و هو موازي للتقدم وجزء من التنمية والاختر اع ويستحيل حدوث تقدم دون الابتكار و الاختر اع و الانجاز و التحصسيل و هو ما يستدعي ويتطلب مر اجعة الجامعة لأفكار هـا ، وبناء أفكار جديدة وثقافات جديدة وتنمية الأخلاق التي يحتاجها المجتمع، وذللك من اجل تعزيز التنمية المستدامة.

و لان التعليم الجـامعي لـه الأثر الأكبر في التنميـة الاقتصـادية والاجتماعيـة ، فهو تعلـيم ذو مو اصفات خاصة تجعله عاملا أساسيا من عوامل التنمية ، وتو اجه الجامعات وخاصة في الدول النامية مسؤوليات متعددة بجانب مسؤولياتها الأكاديمية وذلك باللنسبة لدور ها المتصل باللحاق بالتقدم العلمي و التطور التكنولوجي السريع، وهي مسؤولية تتمثل بالأطوار الآتية:

- - نقل التكنولوجيا المعاصرة، و هي عملية تأخذ في حساباتها نوعية النمط المناسب و الإعداد اللازم و التخطيط السليم لتحقيق عائد مقبول لعملية تعتبر في حد ذاتها استثمار ا ضخما. 
r- - تطوير ما ينقل من أنماط التكنولوجيا بحيث تو اعم مقتضيات وأهداف خطط التنمية الاقتصادية و الاجتماعية.

r- إيداع تطور علمي وتكنولوجي ينبع من ذات المجتمع ويتلاءم مع طبيعته واحتباجاته على المدى القصير

و التعليم الجامعي أمـر لازم بالنسبة للمجتمعـات المتقدمة حتى تحافظ على تقدمها ، و هو أمـر

أكثر لزوما بالنسبة للمجتمعات النامية للأسباب آلاتية :

ا - ان الثروة البشرية في هذه المجتمعات تمثل العنصر الرئيس من عناصر الإنتاج ومن ثم فأن

بر امج التنمية فيها تعنمد في كثير من جو انبها على طريقة إعداد هذا العنصر و استخدامه . Y- ان هناك حاجة ملحة بالنسبة لهذه المجتمعات لان تحقق معدلات نمو عالية كي تلحق بركب التقدم و الرخاء، أو على الأقل حتى لا تتسع الفجوة القائمة بينها وبين المجتمعات المتقدمة . و لا شك ان التعليم الجامعي في العراق يتحمل مسؤولية كبيرة بالنسبة لتلك العناصر البشرية التي جاء عليها الدور لتتحمل أعباء تنمية المجتمع في مسيرته التنموية . أولا : الصادر العربية

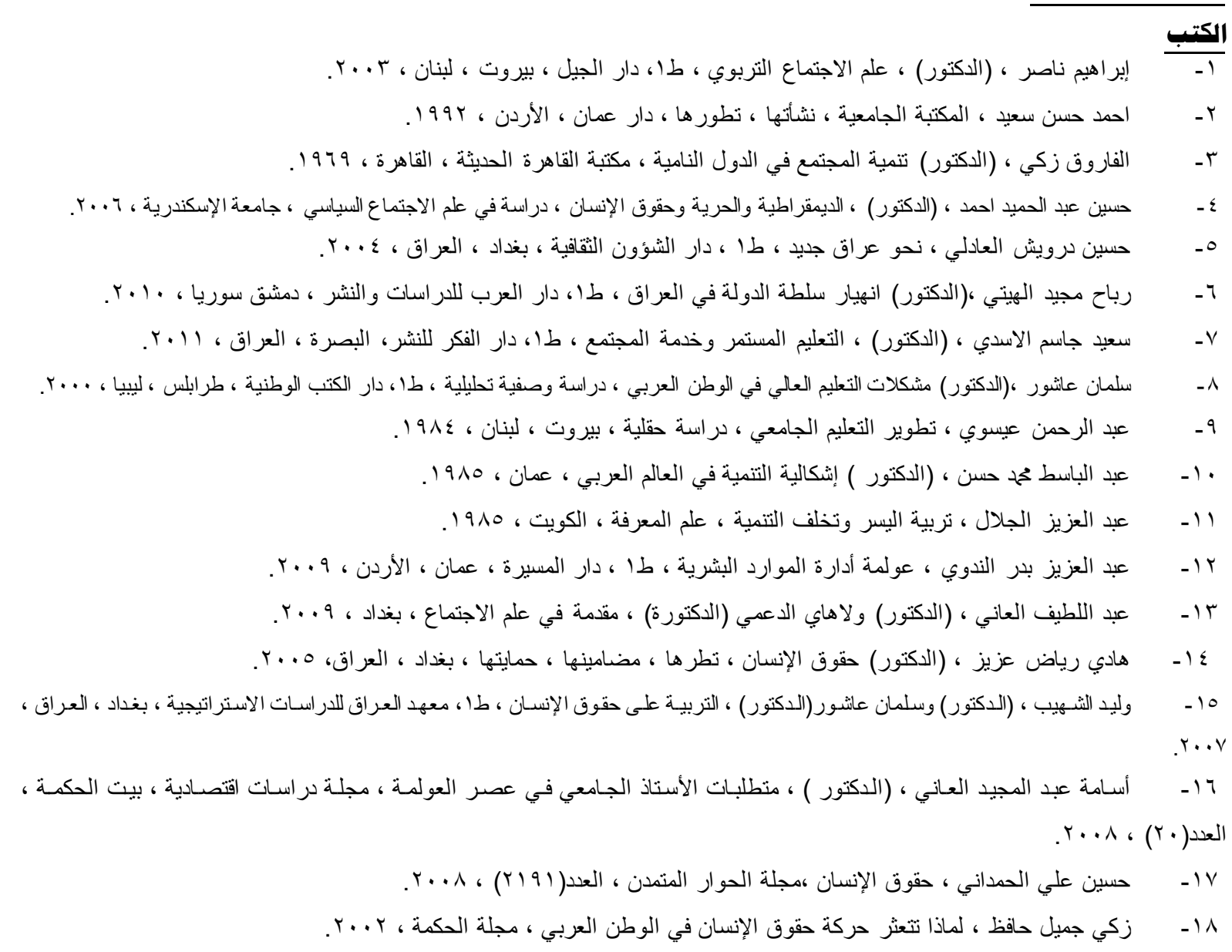




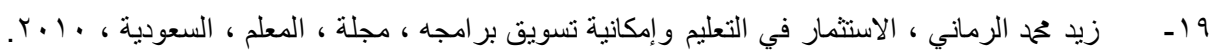

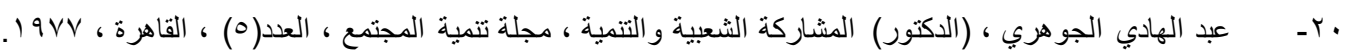

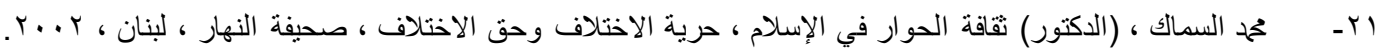

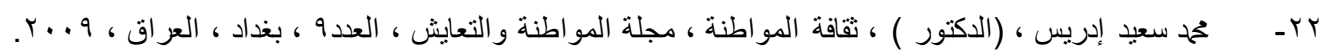

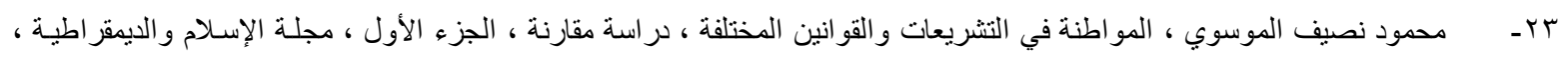

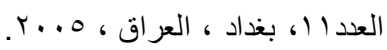

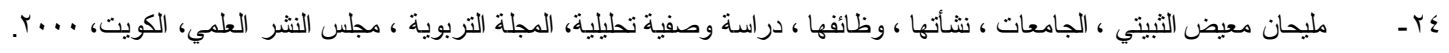

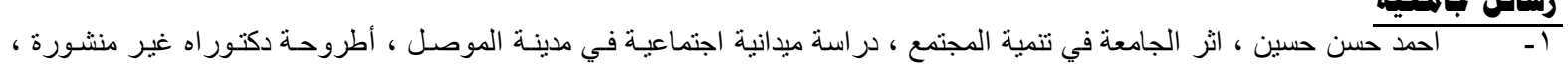

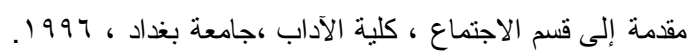

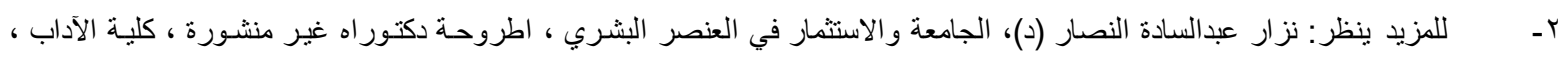

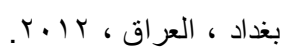

البحوث و التقارير

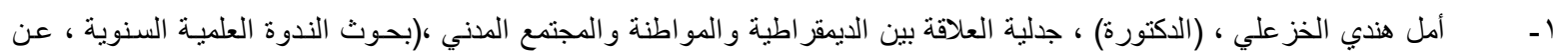

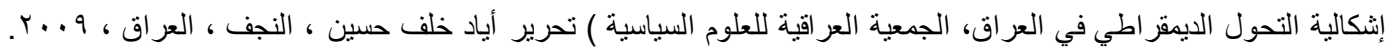

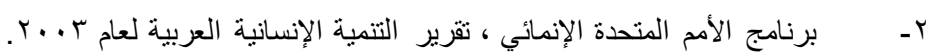

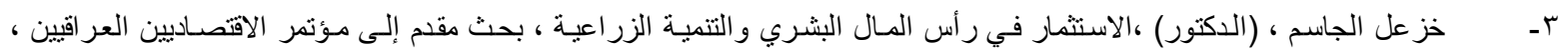

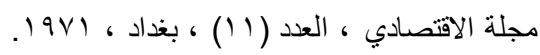

ع - علي حمح جبران ،(الدكتور) إنماء ثقافة الحوار بين طلبة الجامعات ، مـؤتمر الدور الثقافي ، في الجامعات الأردنيـة ، اربد ، الأردن ،

r...V

○ـ عبد الله عبد الدايم ، وآخرون ، تتمية الموارد البشرية ، بحوث ومناقثات ندوة تتمية الموارد البشرية في الوطن العربي ، دار الرازي 191v ، الكويت ،

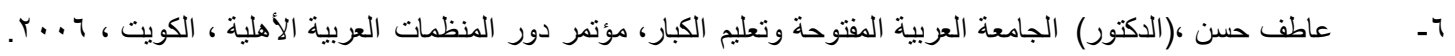

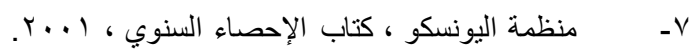

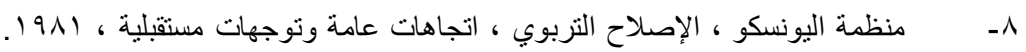

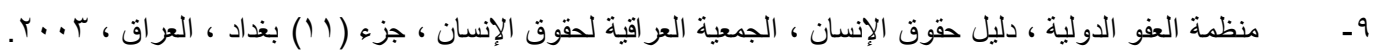

الموسو عات و المعاجم

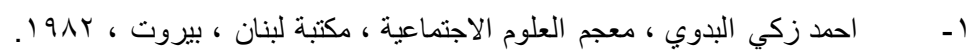

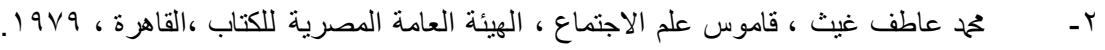

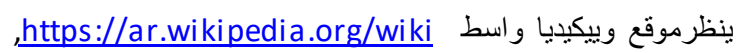

المواقع الالكتزونية

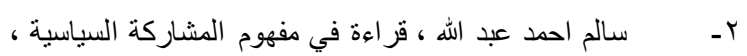

-www.sarayanews.com/object

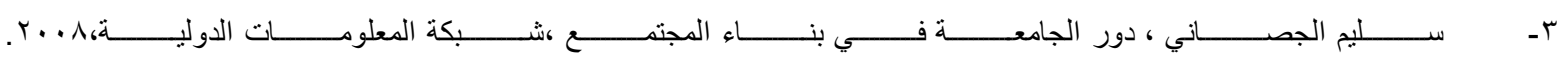
www.annabaa.org/news/maqalat

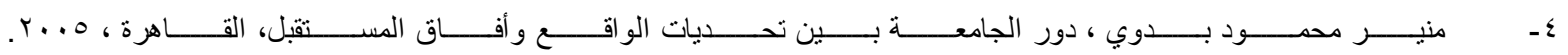

http://www.biblioislam.net

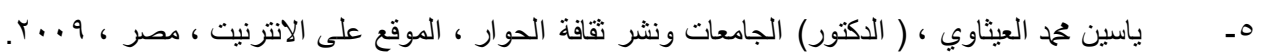

